\title{
Microtensile Bond Strength of a Repair Composite to Leucite-Reinforced Feldspathic Ceramic
}

\author{
Renata Marques de MELO ${ }^{1,2}$ \\ Luiz Felipe VALANDRO ${ }^{2,3}$ \\ Marco Antonio BOTTINO ${ }^{1,2}$ \\ ${ }^{1}$ Department of Dental Materials and Prosthodontics, School of Dentistry of São José dos Campos, \\ São Paulo State University, São José dos Campos, SP, Brazil \\ ${ }^{2}$ MSD and PhD Programs in Prosthodontics, School of Dentistry of São José dos Campos, \\ São Paulo State University, São José dos Campos, SP, Brazil \\ ${ }^{3}$ Department of Restorative Dentistry, School of Dentistry, Federal University of Santa Maria, Santa Maria, RS, Brazil
}

\begin{abstract}
The purpose of this study was to evaluate the microtensile bond strength of a repair composite resin to a leucite-reinforced feldspathic ceramic (Omega 900, VITA) submitted to two surface conditionings methods: 1) etching with hydrofluoric acid + silane application or 2) tribochemical silica coating. The null hypothesis is that both surface treatments can generate similar bond strengths. Ten ceramic blocks $(6 \times 6 \times 6 \mathrm{~mm})$ were fabricated and randomly assigned to 2 groups $(\mathrm{n}=5)$, according to the conditioning method: G1- 10\% hydrofluoric acid application for 2 min plus rinsing and drying, followed by silane application for $30 \mathrm{~s}$; G2- airborne particle abrasion with $30 \mu \mathrm{m}$ silica oxide particles (CoJet-Sand) for $20 \mathrm{~s}$ using a chairside air-abrasion device (CoJet System), followed by silane application for $5 \mathrm{~min}$. Single Bond adhesive system was applied to the surfaces and light cured ( $40 \mathrm{~s})$. Z-250 composite resin was placed incrementally on the treated ceramic surface to build a $6 \times 6 \times 6 \mathrm{~mm}$ block. Bar specimens with an adhesive area of approximately $1 \pm 0.1$ $\mathrm{mm}^{2}$ were obtained from the composite-ceramic blocks (6 per block and 30 per group) for microtensile testing. No statistically significant difference was observed between G1 $(10.19 \pm 3.1 \mathrm{MPa})$ and G2 (10.17 $\pm 3.1 \mathrm{MPa})(\mathrm{p}=0.982)($ Student's t test; á $=0.05)$. The null hypothesis was, therefore, accepted. In conclusion, both surface conditioning methods provided similar microtensile bond strengths between the repair composite resin and the ceramic. Further studies using long-term aging procedures should be conducted.
\end{abstract}

Key Words: ceramic, surface treatment, repair composite, bond strength.

\section{INTRODUCTION}

Intraoral porcelain might fracture due to factors namely occlusal forces, impact, internal defects and inadequate design (1). With the increasing interest in ceramic restorations, such as inlays, onlays, veneers and all-ceramic crowns, producing an esthetic and functional repair system that avoids over time-consuming and expensive remakes has become challenge (2).

The earlier porcelain-repair systems relied on macromechanical retention, with preparation of grooves or undercuts. In contrast, the current generations of these systems are mostly based on micromechanical and chemical bond, by etching/silane application or grit blasting/silane application on the ceramic surface (3).

Several resin-based materials have been used to repair porcelain restorations. It is suggested that the bond strength between these two types of materials is highly dependent on surface preparation (2). Acid etchings, air abrasion with aluminum oxides or silica coating by means of airbone particle abrasion are the most commonly types of surface treatment (1). Acids work well on silica-based porcelains, although a strong one, typically hydrofluoric acid, is needed to promote micromechanical retention. Kupiec (4) evaluated three different ceramic surface treatments: a) aluminum ox-

Correspondence: Prof. Dr. Luiz Felipe Valandro, Departamento de Odontologia Restauradora, Faculdade de Odontologia, Universidade Federal de Santa Maria, Rua Marechal Floriano, 1184, 97015-372 Santa Maria, Brasil. Tel: +55-55-3220-9275. Fax: +55-55-3220-9272. e-mail: 1fvalandro@hotmail.com 
ide $\left(\mathrm{Al}_{2} \mathrm{O}_{3}\right)$ air abrasion $(50 \mu \mathrm{m})$, b) $8 \%$ hydrofluoric acid, and c) air abrasion and hydrofluoric acid. The last combination recorded the most consistently effective bond strengths. Aluminum oxide abrasion provides a clean and reactive bonding surface in porcelains.

A tribochemical silica coating method has been successfully used. In this technique, the surfaces are abraded with $30 \mu \mathrm{m} \mathrm{Al}_{2} \mathrm{O}_{3}$ modified with silicon acid and then silica coating is performed. The silane is applied to react with the coated silica (5-7). The tribochemical silica coating provides fine mechanical retention, as well as physicochemical bonding between resin materials and ceramic, metal and composite restoratives (8).

However, silica coating has been suggested to aluminum-, aluminum/zirconium-, zirconium-based ceramic because etching of these ceramics does not degrade their compact surface of high crystal content, e.g., silica coating is indicated to acid-resistant ceramics with low silica content $(7,9)$. Thus, bonding resin cements to feldspar-based porcelains with high silica content seems to be well established, by treating them with hydrofluoric acid and silane agents. Additionally, in theory, silica coating should not be the treatment of choice for silica-based ceramics because these materials already have silica to their chemomechanical bonding.

Adhesion between two substrates is traditionally studied using shear or tensile bond strength tests. It has been suggested that tensile testing may be better indicated to determine the ceramic-to-composite resin bond strength, as shearing testing evaluate the base material rather than the strength at the adhesive interface. It has also been stated that small-sized specimens have higher bond strength when submitted to microtensile testing $(10,11)$. The effects of pretreatments on porcelain can also be examined by scanning electron microscopy.

The purpose of this study was to evaluate the microtensile bond strength of a repair composite resin to leucite-reinforced feldspathic ceramic submitted to two surface conditionings methods (etching with hydrofluoric acid + silane application or tribochemical silica coating). The null hypothesis is that both surface treatments can generate similar bond strengths.

\section{MATERIAL AND METHODS}

Ten ceramic blocks $(6 \times 6 \times 6 \mathrm{~mm})$ of leucitereinforced feldspathic ceramic (Omega 900, Vita Zahnfabrik, Germany; Batch \#5335; Dentine 4M2) were fabricated. One of the surfaces of each ceramic block was polished with \# 300-, 600-, 800-, 1000- and 1200 -grit $\mathrm{SiC}$ papers. The ceramic blocks were randomly assigned to 2 groups $(\mathrm{n}=5)$, according to the surface treatment: Group 1 (HF) - 6\% hydrofluoric acid (Porcelain Etchant; Bisco Inc., Schaumburg, IL, USA; Batch \#0006) was applied for $60 \mathrm{~s}$ to porcelain surface, rinsed, dried and a coat of silane agent (Porcelain Primer; Bisco Inc.; Batch \#0300012763) was applied and left to dry for $30 \mathrm{~s}$; Group 2 (CoJet - tribochemical silica coating) - ceramic surface was submitted to airborne particle abrasion with $30 \mu \mathrm{m}$ silica oxide particles (CoJet-Sand) (sandblasting parameters: aposition: perpendicular to the surface; $b$ - distance: 10 $\mathrm{mm}$; c- time: $20 \mathrm{~s}$; d- pressure: 2.8 bars) using a chairside air-abrasion device (CoJet System; 3M/ESPE, St. Paul, MN, USA; Batch \#68421), followed by silane application (Sil; 3M/ESPE) for $5 \mathrm{~min}$.

After surface treatments, Single Bond adhesive system (3M/ESPE; Batch \#1105) was applied to ceramic surface and light cured for $20 \mathrm{~s}$ (XL 3000, 3M/ ESPE; light intensity $=500 \mathrm{~mW} / \mathrm{cm}^{2}$; distance $\left.=0\right) . Z-250$ composite resin (3M/ESPE; Batch \#3CE) was accommodated incrementally on the treated ceramic surface to build a $6 \times 6 \times 6 \mathrm{~mm}$ block. The resin was used in $2-\mathrm{mm}-$ thick increments, each polymerized for $40 \mathrm{~s}$.

After a 7-day storage in distilled water at $37^{\circ} \mathrm{C}$, the ceramic/resin blocks were taken to a precision cutting machine with a water-cooled diamond saw (Labcut 1010; Extec Corp., Enfield, CT, USA) (Figs. 1 and 2). In all bocks, the first cuts $( \pm 0.5 \mathrm{~mm})$ were discarded because results could be influenced by excess or lack of adhesive at the interface. Next, 3 approximately 1-mm-thick slices were cut from each block (Fig. 1). Next, each slice was rotated $\left(90^{\circ}\right)$ and bonded to other metallic bases (Fig. 2). The initial portion $( \pm 0.5 \mathrm{~mm})$ was discarded for the same reasons described above. Other three approximately 1 -mm-thick slices were obtained. A total of nine specimens per ceramic/resin block and 45 specimens per group were obtained (Fig. 2). The specimens had the following characteristics (Fig. 2C): a- non-trimmed rectangular form (bar specimens); b- nearly symmetric square cross-section area of $1 \pm 0.1 \mathrm{~mm}^{2}$; c- length of about $10 \mathrm{~mm}(7,11,12)$.

\section{Microtensile Bond Strength Test}

Before testing, the adhesive area of each bar was 
measured using a digital caliper (Mitutoyo, Tokyo, Japan). Each specimen was bonded with cyanoacrylate adhesive to a custom-made device perpendicular to the force applied, therefore avoiding sprain forces at the interface. Only the ends of the specimen were bonded. The device/specimen set was adapted to a universal testing machine (Emic DL-1000; Emic, São José dos Pinhais, PR, Brazil) and tested in microtensile strength at crosshead speed of $1 \mathrm{~mm} . \mathrm{min}^{-1}$ until fracture. Microtensile bond strength calculations were made using the following equation: $\sigma=\mathrm{L} / \mathrm{A}$, where $\sigma$ is the bond strength $(\mathrm{MPa}), \mathrm{L}=$ test load $(\mathrm{N}), \mathrm{A}=$ adhesive area $\left(\mathrm{mm}^{2}\right)$. The results were analyzed statistically by Student's t-test $(\alpha=0.05)$. The debonded bar specimens were analyzed with a scanning electron microscope (JSM-T330A; Jeol, Tokyo, Japan) at $\times 150$ to evaluate the failure modes (adhesive, cohesive or mixed).

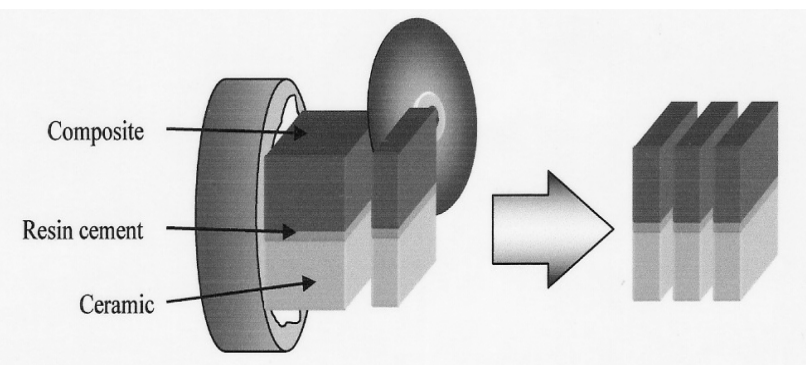

Figure 1. Cutting of the cemented blocks (A); three slices were obtained per block (B).
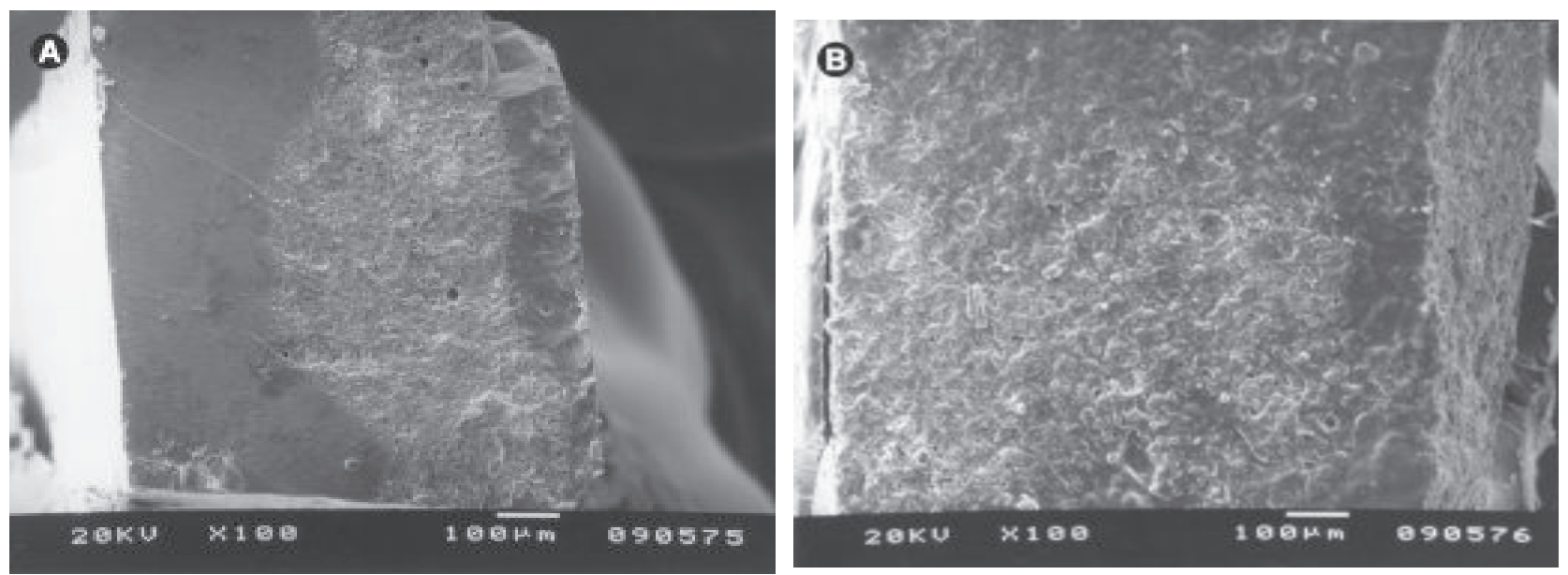

Figure 3. SEM micrograph of a fractured specimen from $\mathrm{G} 1(\times 150)(\mathrm{A})$; SEM micrograph of a fracture specimen from $\mathrm{G} 2(\times 150)(\mathrm{B})$.

\section{Micromorphological Analysis}

The surfaces of two ceramic specimens were submitted to tribochemical silica coating and analyzed topographically under scanning electron microscopy.

\section{RESULTS}

G1 $(10.19 \pm 3.1 \mathrm{MPa})$ and G2 $(10.17 \pm 3.1 \mathrm{MPa})$ presented statistically similar microtensile bond strength means $(\mathrm{p}=0.982)$

Regardless of the experimental group, all (100\%) debonded specimens presented failure in the adhesive zone (Fig. 2D), either adhesive or mixed (adhesive and cohesive of the cement) (Fig. 3A,B).

The topographic analysis showed that the acidetched ceramic surface (Fig. 4A) was rougher (more

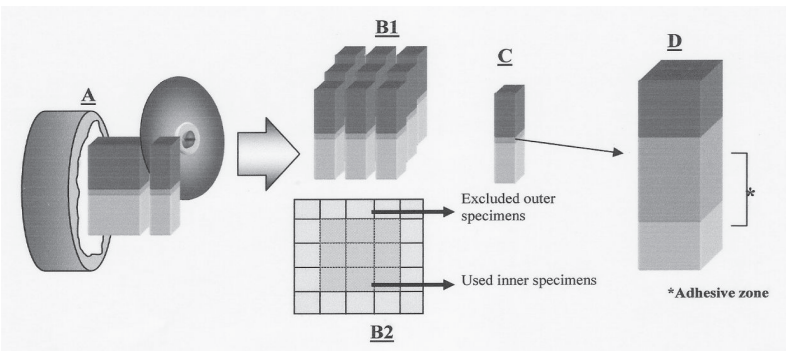

Figure 2. Slice cutting (A); Specimens obtained per block (B1); Specimens used (B2); Bar specimen (C); adhesive zone (D). 
irregularities) than those coated with silica oxide particles (Fig. 4B).

\section{DISCUSSION}

By using porcelain-repair systems, porcelain can be repaired without removal of the prosthesis. This study sought to determine the best surface treatment for a leucite-reinforced glass ceramic repaired with a composite resin. Under the tested experimental conditions, both ceramic surface treatments provided similar bond strengths between the leucite-reinforced feldspar ceramic and the repair composite resin. The null hypothesis was therefore accepted.

The mean microtensile bond strength data recorded in the present investigation are concistent with those of previous studies $(2,6)$ and are much lower than the reasonable composite-to-dentin bond strength goal stated in the literature (20 MPa). Matsumura et al. (13) showed that all systems used to produce mechanical or chemical adhesion between substrates should provide at least $10 \mathrm{MPa}$ of bond strength to be indicated for clinical situations. The low values might be attributed to the fact that contemporary porcelain repair systems provides mostly chemical rather than mechanical bonding to porcelain. The former repair systems offer a type of treatment that can lead to lower bond strength under water storage and/or thermocycling, which, however, was not performed in this study.

Regarding the topographic patterns produced by the treatments on ceramic surface, the specimens etched with HF (Fig. 4A) presented a rougher surface (more irregularities) than the ones abraded with silica oxide particles (Fig. 4B). Chemical and mechanical treatments of porcelain surfaces increase the total surface area and the surface energies as well. According to Phoenix and Shen (14), this mechanical interlocking exerts significant effects upon the formation and maintenance of ceramic-to-resin bond. To make leucitebased ceramic more wettable, preparation of numerous small and uniform pits or grooves are preferred (16).

On the other hand, the ceramic surface coated by silica oxide presents high chemical reactivity to resin materials. $(1,3,7,8,17)$. Bonding to ceramic substrates seems to be dependent on the presence of silica in their surfaces, which has great affinity for silane agents (5). As the silica layer is well incorporated to ceramic surface, silane application enhances the resin bond. In view of these results, there is a trend to choose the silica coating for repairing porcelain substrates (16). Kern and Thompson (9) stated that silica coating can improve bonding of resin to glass-infiltrated aluminum oxide ceramic (In-Ceram), but they also stated that sandblasting of all-ceramic restorations with feldspar glass materials should be avoided because of the great volume loss produced by sandblasting. Therefore, sandblasting of feldspar-based ceramic with aluminum oxide particles can damage ceramic surface and hence it should not be indicated in such cases.

HF etching, which consists of a preferential
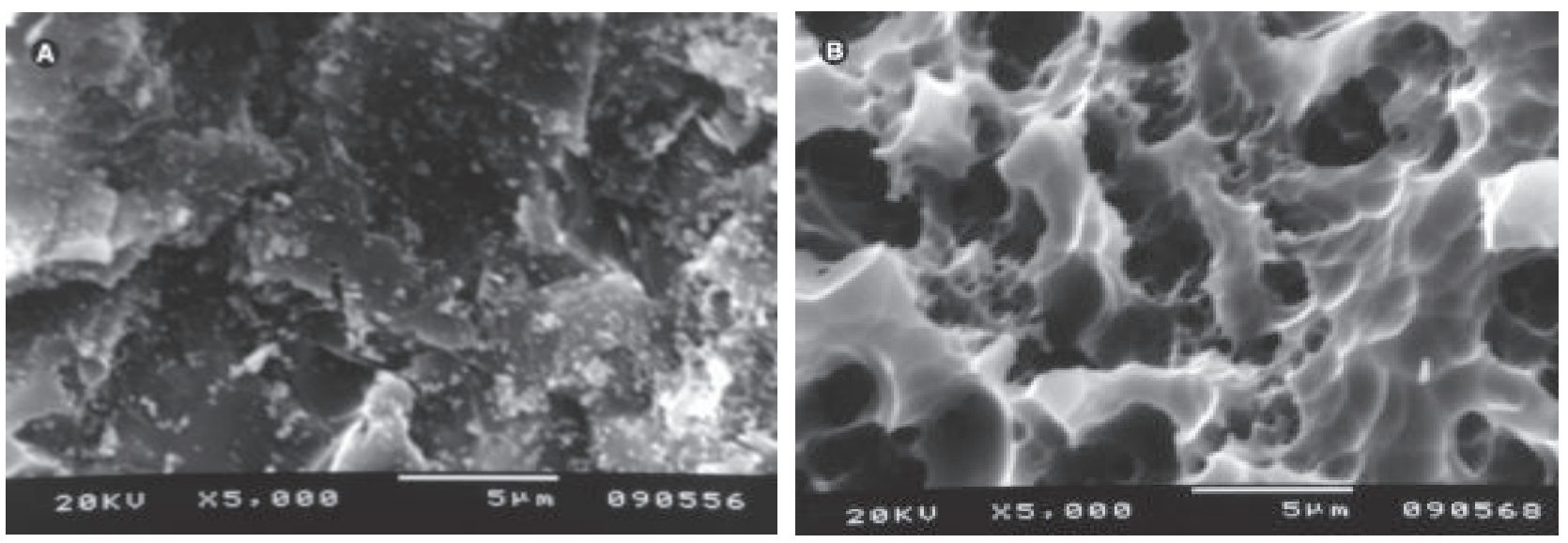

Figure 4. SEM micrograph of the ceramic surface abraded with $30 \mu \mathrm{m}$ silica oxide particles $(\times 5000)(\mathrm{A})$. SEM micrograph of the ceramic surface etched with $6 \%$ hydrofluoric acid for $2 \min (\times 5000)(B)$. 
attack of the leucite phase resulting in a retentive surface, can also provide reasonable bond strengths between composite and ceramic, especially when followed by silane application (4). The variety of concentrations of commercially available hydrofluoric acids indicates that the optimal concentration and duration of their application are not well established (17).

However, all ceramic restorations are prone to crack propagation through the glass matrix, leading to failures. Intrinsic microscopic defects are also responsible for cracks and catastrophic fractures of these materials. Thus, the following relations are possible: a) the higher the amount of glass, the lesser the ceramic strength (acid sensitive-ceramics); b) the lower the amount of glass and the higher the content of crystals, the higher the ceramic strength (acid resistant-ceramics).

In this sense, traditional adhesive procedures can contribute to strengthen less resistant ceramics. HF etching and adhesive cementation can limit crack propagation, especially because the cement can infiltrate and seal the failures created by acid attack (18). Silane agents improve the chemical bonding between ceramic and resin cement and also fill intra-ceramic defects.

There is a noteworthy difference from the experimental design of many studies to the present one. Shear strength test has been the most commonly employed test modality to study the performance of porcelain repair systems. But it is believed that this test geometry causes high tensile surface stresses within the porcelain, close to the area of load application, initiating fracture at the porcelain surface. Tensile strength test would more likely provide adhesive failures between materials because the load is applied perpendicularly to the long axis of the sample, avoiding the occurrence of sprain forces and shearing stresses on the adhesive area (10). The dimensions of the specimens in the present study were based on the inverse relationship between bond strength and bond surface area, as published elsewhere (12).

Thus, for a test to reproduce the real bond strength between an adhesive (resin cement) and an adherent (dental, metallic, ceramic or polymeric-substrate), it is essential that the interfacial zone is the most stressed area, notwithstanding the mechanical test used (12). According to a stress distribution study (19), some mechanical tests do not actually stress the interfacial zone. The shear test, for example, is criticized because the stress is non-homogeneously distributed at the adhesive interface, requiring more substrate. Thus, the stresses are concentrated in a restricted zone distant from the adhesion zone and hence most fractures occur in the substrate. This phenomenon prevents the measurement of true interfacial bond strength and limits further improvements in the bonding systems (under estimated and misinterpreted results). The analysis of the failure mode and fractography reduce the risk of data misinterpretation, such as stating that "The bond strength was higher than the cohesive strength of the substrate" (11).

Within the limitations of this investigation, it may be concluded both surface conditioning methods provided similar microtensile bond strengths between the repair composite resin and the ceramic. Further studies using long-term aging procedures should be conducted.

\section{RESUMO}

A proposta desse estudo foi avaliar a resistência à microtração entre uma resina composta e uma cerâmica feldspática submetida a diferentes tratamentos de superfície. A hipótese foi que os tratamentos de superfície (deposição de sílica + silanização e o ácido fluorídrico + silanização) promovessem resistências adesivas semelhantes. Dez blocos cerâmicos (Omega 900) de 6x6x6mm foram confeccionados e divididos em dois grupos: G1 - ácido fluorídrico 10\%/2 min + silanização; G2 - Sistema CoJet: jateamento com partículas de sílica de $30 \mu \mathrm{m}$ (CoJet-Sand) + ESPE-Sil. Em seguida, o adesivo Single Bond foi aplicado na superfície e fotopolimerizado ( $40 \mathrm{~s}$ ); a resina composta Z-250 foi condensada, obtendo-se um bloco de $6 \mathrm{~mm}$. Depois da armazenagem (água destilada $/ 37^{\circ} \mathrm{C} / 7$ dias), espécimes retangulares foram seccionados com disco diamantado (6 corpos-de-prova por bloco e 30 corpos-de-prova por grupo), com $1 \pm 0,1 \mathrm{~mm}^{2} \mathrm{de}$ área adesiva. Cada corpo-de-prova foi fixado a um dispositivo adaptado com cianoacrilato e o teste de tração foi realizado. Os dados foram submetidos ao Teste $t$ de Student $(p>0,05)$. A hipótese nula foi aceita ( $\mathrm{p}=0.982)$ : G1 $(10,19 \pm 3,1 \mathrm{MPa})$ e G2 $(10,17 \pm 3,1 \mathrm{MPa})$ foram similares estatisticamente. Concluiu-se que os métodos de condicionamento da superfície cerâmica geram resistência adesiva similar à da cerâmica. Estudos posteriores empregando envelhecimento a longo prazo devem ser realizados.

\section{ACKNOWLEDGEMENTS}

The authors would like to thank Wilcos do Brasil, VITA Zahnfabrik, Bisco, and 3M/ESPE for providing some of the materials used in this study.

\section{REFERENCES}

1. Haselton DR, Diaz-Arnold A, Dunne Jr JT. Shear bond strengths of 2 intraoral porcelain repair systems to porcelain or metal substrates. J Prosthet Dent 2001;86:526-531. 
2. Pameijer CH, Louw NP, Fisher D. Repairing fractured porcelain: how surface preparation affects shear force resistance. J Am Dent Assoc 1996;127:203-209.

3. Hooshmand T, Van Noort R, Keshvad A. Bond Durability of the resin bonded and silane treated ceramic surface. Dent Mater 2002;18:179-188.

4. Kupiec KA, Wuertz KM, Barkmeier WW, Wilwerding TM. Evaluation of porcelain surface treatments and agents for composite-to-porcelain repair. J Prosthet Dent 1996;76:119124.

5. Söderholm KJ, Shang SW. Molecular orientation of silane at the surface of colloidal silica. J Dent Res 1993;72:10501054.

6. Frankenberger R, Kramer N, Sindel J. Repair strength of etched vs silica-coated metal-ceramic and all-ceramic restorations. Oper Dent 2000;25:209-215.

7. Valandro LF, Ozcan M, Bottino MC, Bottino MA, Scotti R, Bona $\mathrm{AD}$. Bond strength of a resin cement to high-alumina and zirconia-reinforced ceramics: the effect of surface conditioning. J Adhes Dent 2006;8:175-181.

8. Ozcan M. The use of chairside silica coating for different dental applications: a clinical report. J Prosthet Dent 2002;87:469-472.

9. Kern M, Thompson VP. Sandblasting and silica coating of a glass-infiltrated alumina ceramic: volume loss, morphology, and changes in the surface composition. J Prosthet Dent 1994;71:453-461.

10. Della Bona A, Van Noort R. Shear vs. tensile bond strength of resin composite bonded to ceramic. J Dent Res 1995;74:15911596.
11. Della Bona A, Anusavice KJ, Shen C. Microtensile strength of composite bonded to hot-pressed ceramics. J Adhesive Dent 2000;2:305-313.

12. Shono Y, Terashita M, Shimada J, Kozono Y, Carvalho RM, Russell CM, Pashley DH. Durability of resin-dentin bonds. J Adhesive Dent 1999;1:211-218.

13. Matsumura H, Yanagida H, Tanoue N, Atsuta M, Shimoe S. Shear bond strength of resin composite veneering material to gold alloy with varying metal surface preparations. J Prosthet Dent 2001;86:315-319.

14. Phoenix S, Shen C. Characterization of treated porcelain surfaces via dynamic contact angle analysis. Int J Prosthodont 1995;8:187-194.

15. Won-Suck O, Shen C, Alegre B, Anusavice KJ. Wetting characteristic of ceramic to water and adhesive resin. J Prosthet Dent 2002;88:616-621.

16. Noel LG, Mitchell WC. Porcelain veneer. Gen Dent 1997;45:182-185.

17. Ozcan M, Vallitu PK. Effect of surface conditioning methods on the bond strength of luting cement to ceramics. Dent Mater 2003;19:725-731.

18. Sindel J, Frankenberger R, Kramer N, Petschelt A. Crack formation of all-ceramic crowns dependent on different core build-up and luting materials. J Dent 1999;27:175-181.

19. Versluis A, Tantbirojn D, Douglas WH. Why do shear bond tests pull out dentin? J Dent Res 1997;76:1298-1307.

Accepted November 9, 2007 